\title{
The effect of vanadate on Pichia pastoris growth, protein kinase A activity and ribosomal protein phosphorylation
}

\author{
Magdalena Frajnt ${ }^{1}$, Małgorzata Cytryńska ${ }^{2}$ and Teresa Jakubowicz ${ }^{2 \bowtie}$ \\ ${ }^{1}$ Department of Molecular Biology, Institute of Microbiology and Biotechnology, and \\ ${ }^{2}$ Department of Invertebrate Immunology, Institute of Biology, Maria Curie-Sktodowska \\ University, Lublin, Poland
}

Received: 02 July, 2002; revised: 10 October, 2002; accepted: 28 October, 2002

Key words: Pichia pastoris, vanadate, PKA, protein kinases, protein phosphorylation, ribosomal proteins

\begin{abstract}
It was found that wild type yeast Pichia pastoris can tolerate vanadate concentration as high as $25 \mathrm{mM}$ in the growth medium. Moreover, four vanadate-resistant $P$. pastoris strains designated JC100/1, JC100/3, JC100/9 and JC100/15 exhibiting tolerance up to $150 \mathrm{mM}$ vanadate were selected. Growth of $P$. pastoris was correlated with vanadate to vanadyl reduction and its accumulation in the growth medium. In two selected strains, JC100/9 and JC100/15, protein kinase A activity was much higher in comparison to the wild type strain even without vanadate addition to the growth medium. Moreover, in the presence of vanadate, protein kinase A activity was significantly increased in the wild type and the vanadate-resistant $\mathrm{JC100/1}$ and JC100/3 strains. It was also found that phosphorylation of a $40 \mathrm{kDa}$ protein associated with ribosomes occured in all vanadate-resistant strains from the logarithmic, while in the wild type strain from the stationary growth phase. From the presented results it can be concluded that a protein kinase A signalling pathway(s) might be involved in the mechanism of $P$. pastoris vanadate resistance. The results also indicate a possible role of the $40 \mathrm{kDa}$ protein in protection of $P$. pastoris against vanadate toxicity.
\end{abstract}

Vanadium is a group $\mathrm{V}$ transition metal, essential for growth and development of many plant and animal organisms. It exists in different oxidation states $\mathrm{V}^{\mathrm{III}}, \mathrm{V}^{\mathrm{IV}}$ and $\mathrm{V}^{\mathrm{V}}$, two of which, vanadate $\left(\mathrm{V}^{\mathrm{V}}\right)$ and the less toxic vanadyl $\left(\mathrm{V}^{\mathrm{IV}}\right)$, are the most common ones under physiological conditions (Rehder, 1992). It is known that vanadium salts can mimic metabolic and growth promoting effects of insulin. They are able to normalize blood glu-

\footnotetext{
${ }^{\circledR}$ Address for correspondence: Teresa Jakubowicz, Department of Invertebrate Immunology, Maria Curie-Skłodowska University, Akademicka 19, 20-033 Lublin, Poland; tel.: (48 81) 537 5089; e-mail: tejak@biotop.umcs.lublin.pl

Abbreviations: PKA, cyclic AMP dependent protein kinase; MAP kinases, mitogen activated protein kinases.
} 
cose concentration in both type I and type II diabetes mellitus. Therefore, there is an interest in the use of vanadate derivatives for the treatment of diabetes (Morinville et al., 1998).

Vanadate becomes toxic when present intracellularly at concentrations higher than micromolar. The mechanism of the vanadate toxic effect is connected with its structural similarity to phosphate. As a phosphate analog vanadate inhibits the activity of enzymes of phosphate metabolism such as: ATPases (Karlish et al., 1979; Wach \& Graber, 1991), RNAases (Lindquist et al., 1973), adenylate kinases, phosphofructokinases (Chasteen, 1984) and phosphoprotein phosphatases (Morinville et al., 1998). There are, however, organisms which tolerate high vanadium concentrations as, for example, some species of marine tunicates which can accumulate as high as $1 \mathrm{M}$ concentration of this metal in specialized cells - vanadocytes (Carlson, 1975). Vanadate-resistant mutants of the filamentous fungus Neurospora crassa (Bowman et al., 1983) and several yeast species: Candida albicans (Mahanty et al., 1991), Saccharomyces cerevisiae (Kanik-Ennulat et al., 1995) and Hansenula polymorpha (Mannazzu et al., 1997) were also described. The mechanism of resistance of these organisms to vanadium is still not elucidated. It was hypothesized that in vanadate-resistant mutants of $N$. crassa (Bowman et al., 1983) and C. albicans (Mahanty et al., 1991) the resistance to vanadium is due to vanadate exclusion from the intracellular compartment as a consequence of the inactivation of the phosphate transport system. In contrast, in the yeast $S$. cerevisiae vanadate-resistant mutants, the phosphate transport system was not altered. According to Willsky et al. (1984) and Zoroddu et al. (1996) the vanadate oxyanion, after entering the cells by the phosphate transport system, is reduced to the less toxic vanadyl and then excreted outside the cell. In other report Bisconti et al. (1997) suggested that in the SC-1 vanadate-resistant strain of $S$. cerevisiae the vanadate to vanadyl reduction occured at the level of the cell envelope and not intracellularly. It was also shown that in the yeast $S$. cerevisiae vanadate inhibits the release of secretory vesicles (Lew \& Sanford, 1991) and vanadate-resistant mutants show defects in glycosylation and in the secretory pathway (Kanik-Ennulat et al., 1995). For the methyltrophic yeast $H$. polymorpha it was proposed that the detoxication mechanism is based on the accumulation of toxic metal ions complexed with polyphosphates in vacoules (Mannazzu et al., 1997).

In this paper we present studies on vanadate effect on the growth of the yeast Pichia pastoris, protein kinase A activity and ribosomal protein phosphorylation. The studies were performed on the wild type and four vanadate-resistant strains selected in our laboratory.

\section{MATERIALS AND METHODS}

Strain and growth conditions. Pichia pastoris, strain JC100 (Cregg Lab., Oregon Institute of Science and Technology, Portland, U.S.A.) was grown under aerobic conditions in YPD medium (1\% yeast extract, $2 \%$ peptone, $2 \%$ glucose) at $28^{\circ} \mathrm{C}$ to the exponential or stationary growth phase.

Preparation and storage of sodium orthovanadate stock solutions. Stock solutions of sodium orthovanadate (Sigma) were prepared in deionized water, adjusted to $\mathrm{pH}$ 5.8 with $6 \mathrm{M} \mathrm{HCl}$, filter sterilized and stored at $4^{\circ} \mathrm{C}$. To ensure the presence of monomers in the solution and to eliminate polymeric species of $\left(\mathrm{V}_{10} \mathrm{O}_{28}\right)^{6-}$ which are orange-yellow in colour, $\mathrm{pH}$ adjustment was performed stepwise with heating the solution to boiling until translucent after each part of $6 \mathrm{M} \mathrm{HCl}$ had been added (Goodno, 1979; Gordon, 1991).

Selection of vanadate-resistant strains of P. pastoris. Approximately $10^{8}$ cells from an overnight culture of the wild type strain $P$. pastoris JC100 were spread onto YPD agar plates containing sodium orthovanadate at 
concentrations up to $30 \mathrm{mM}$ and incubated for 5 days at $28^{\circ} \mathrm{C}$. One-hundred vanadate-resistant colonies were selected and cultivated on solid YPD medium containing from $50 \mathrm{mM}$ to $150 \mathrm{mM}$ sodium orthovanadate under the same conditions. Four strains, designated JC100/1, JC100/3, JC100/9, JC100/15, resistant to $150 \mathrm{mM} \mathrm{Na} 3 \mathrm{VO}_{4}$ were isolated.

For the growth kinetics assessment the vanadate-resistant strains were grown in liquid YPD medium without sodium orthovanadate or in the presence of $25 \mathrm{mM}$ and 50 $\mathrm{mM} \mathrm{Na}_{3} \mathrm{VO}_{4}$ under aerobic conditions at $28^{\circ} \mathrm{C}$ for $80 \mathrm{~h}$. Yeast growth was measured in terms of absorbance at $600 \mathrm{~nm}$. The kinetics of vanadyl production was analyzed by the absorbance measured at $767 \mathrm{~nm}$ in cell-free medium (Bisconti et al., 1997).

Preparation of yeast cell-free extracts and protein kinase $A$ assay. Yeast cells from the exponential growth phase were harvested by centrifugation and washed three times in distilled water. Cell-free extracts were prepared in a buffer containing $50 \mathrm{mM}$ Tris/HCl, pH 7.5, 6 mM 2-mercaptoethanol, $10 \mathrm{mM} \beta$-glycerophosphate, $1 \mathrm{mM}$ phenylmethylsulfonyl fluoride (PMSF) and $0.5 \mathrm{mM}$ EDTA, as described previously (Cytryńska et $a l .$, 1999).

PKA activity was determined in the preparations obtained from cell-free extracts by ammonium sulfate precipitation at $70 \%$ saturation. The standard reaction mixture $(50 \mu \mathrm{l})$ contained: $20 \mathrm{mM}$ Tris/ $\mathrm{HCl}, \mathrm{pH} 7.5,10 \mathrm{mM}$ $\mathrm{Mg}\left(\mathrm{CH}_{3} \mathrm{COO}\right)_{2}, 5 \mathrm{mM}$ 2-mercaptoethanol, 15 $\mu \mathrm{g}$ protamine sulfate, $2 \mu \mathrm{M}$ cAMP or cGMP, $0.03 \mathrm{mM}\left[\gamma^{32} \mathrm{P}\right] \mathrm{ATP}\left(450\right.$ c.p.m. $\times \mathrm{pmol}^{-1}$ ) and crude PKA fraction (2-10 $\mu \mathrm{g}$ protein). After incubation at $30^{\circ} \mathrm{C}$ for 20 min the reaction mixture was spotted onto phosphocellulose filter (Whatman P81) and washed three times in $15 \%$ acetic acid. The radioactivity was determined in a scintillation counter (Cytryńska et al., 2001).

Preparation of ribosomes and ribosomal protein phosphorylation. Membrane-free
80S ribosomes were released from the endoplasmic reticulum by $1 \%$ Triton X-100 treatment of the microsomal fraction. These ribosomal preparations were used for phosphorylation of ribosomal proteins by ribosome-bound protein kinases (Wojda et al., 1999).

The standard reaction mixture in a total volume of $50 \mu \mathrm{l}$ contained: $50 \mathrm{mM}$ Tris/ $\mathrm{HCl}, \mathrm{pH}$ 7.5, $10 \mathrm{mM} \mathrm{Mg}\left(\mathrm{CH}_{3} \mathrm{COO}\right)_{2}, 1 \mathrm{mM}$ dithiothreitol (DTT), $150 \mu \mathrm{g}$ of ribosomes and 0.09 $\mathrm{mM}\left[\gamma_{-}{ }^{32} \mathrm{P}\right] \mathrm{ATP}$. The mixture was incubated at $30^{\circ} \mathrm{C}$ for $20 \mathrm{~min}$ and the reaction was stopped by the addition of $25 \mu \mathrm{l}$ Laemmli sample buffer (1970). The phosphorylation level of ribosomal proteins and proteins associated with ribosomes was analysed by electrophoresis in SDS-containing $12 \%$ polyacrylamide slab gels (SDS/PAGE) according to Laemmli (1970) and subsequent autoradiography.

For isoelectrofocusing (IEF) analysis the samples after incubation, containing 1-1.5 $\mathrm{mg}$ of membrane-free ribosomes in $500 \mu \mathrm{l}$ of reaction mixture, were diluted in $50 \mathrm{mM}$ Tris/HCl, $\mathrm{pH} 7.5,10 \mathrm{mM} \mathrm{Mg}\left(\mathrm{CH}_{3} \mathrm{COO}\right)_{2}, 1$ mM DTT buffer. The ribosomes were sedimented by centrifugation at $100000 \times \mathrm{g}$. Ribosomal acidic proteins were extracted with $0.25 \mathrm{M} \mathrm{NH}_{4} \mathrm{Cl} / 50 \%$ ethanol and then suspended in $20 \mu \mathrm{l}$ of a solution of $6 \mathrm{M}$ urea and $2 \%$ ampholine $\mathrm{pH}$ 2.5-5.0. Proteins were resolved by isoelectrofocusing using $5 \%$ polyacrylamide $(\mathrm{w} / \mathrm{v})$ gels with $6 \mathrm{M}$ urea and $2 \%$ ampholines in the 2.5 to $5.0 \mathrm{pH}$ range (Juan-Vidales et al., 1984). The separated proteins were silver stained and radioactive phosphoproteins were detected by autoradiography.

Determination of protein concentration. The concentration of protein was determined by the Bradford method (Bradford, 1976) using bovine serum albumin as a standard.

Determination of ribosome concentration. The concentration of ribosomes (1 $\mathrm{mg} / \mathrm{ml}$ has $\mathrm{A}_{260}=11$ ) was estimated according to Van der Zeijst et al. (1972). 


\section{RESULTS}

\section{Vanadate effect on $P$. pastoris growth}

Four P. pastoris strains designated JC100/1, JC100/3, JC100/9, JC100/15 exhibiting tolerance up to $150 \mathrm{mM}$ concentration of vanadate were selected on YPD agar plates as described in the Materials and methods section. The growth kinetics of these strains in liquid YPD medium in the absence and in the presence of $25 \mathrm{mM}$ and $50 \mathrm{mM}$ sodium orthovanadate were assessed. As can be seen in Fig. 1 , the growth curves were similar for the con-
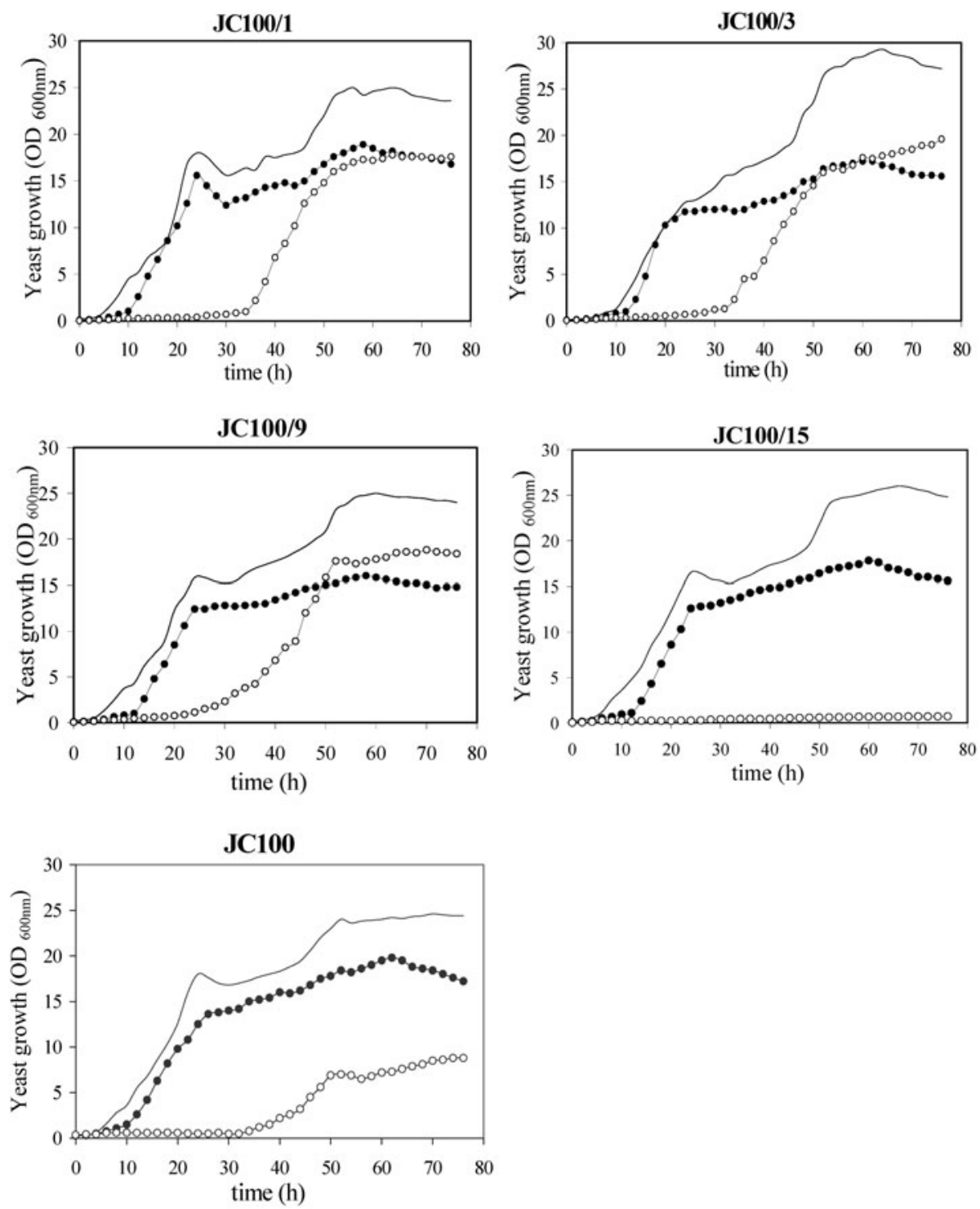

Figure 1. Growth curves of wild type and vanadate-resistant P. pastoris strains on YPD liquid medium.

(-) Without sodium orthovanadate; (O) with $25 \mathrm{mM}$ sodium orthovanadate; $(O)$ with $50 \mathrm{mM}$ sodium orthovanadate. The presented growth curves are representative for three independent experiments. 
culture was caused by the reduction of vanadate to vanadyl as was reported by Bisconti et al. (1997). As can be seen in Fig. 2, a significant increase in the vanadate to vanadyl reduction occured after $5 \mathrm{~h}$ of culturing in the medium with $25 \mathrm{mM}$ vanadate, while with $50 \mathrm{mM}$ vanadate significant production of vanadyl occured only after a $30 \mathrm{~h}$ lag phase. Without vanadate, the colour of the yeast suspension remained unchanged. In the case of strain $\mathrm{JC} 100 / 15$, which did not grow in the presence of $50 \mathrm{mM}$ vanadate (Fig. 1), vanadyl was also not detected in the growth medium (Fig. 2). The obtained results indicate

\section{Studies of PKA activity in $P$. pastoris} vanadate-resistant strains

It is known that vanadate is a phosphoprotein phosphatases inhibitor in vitro while vanadyl in vivo appeares to stimulate protein phosphorylation. This indicates that vanadium can interfere with cellular regulation processes. Vanadium compounds can stimulate the activity of adenylate cyclase which controls cAMP level in the cell and as a consequence can affect PKA activity (Hackbarth et al., 1980; Catalan et al., 1980). Therefore, we determined PKA activity in the wild type and
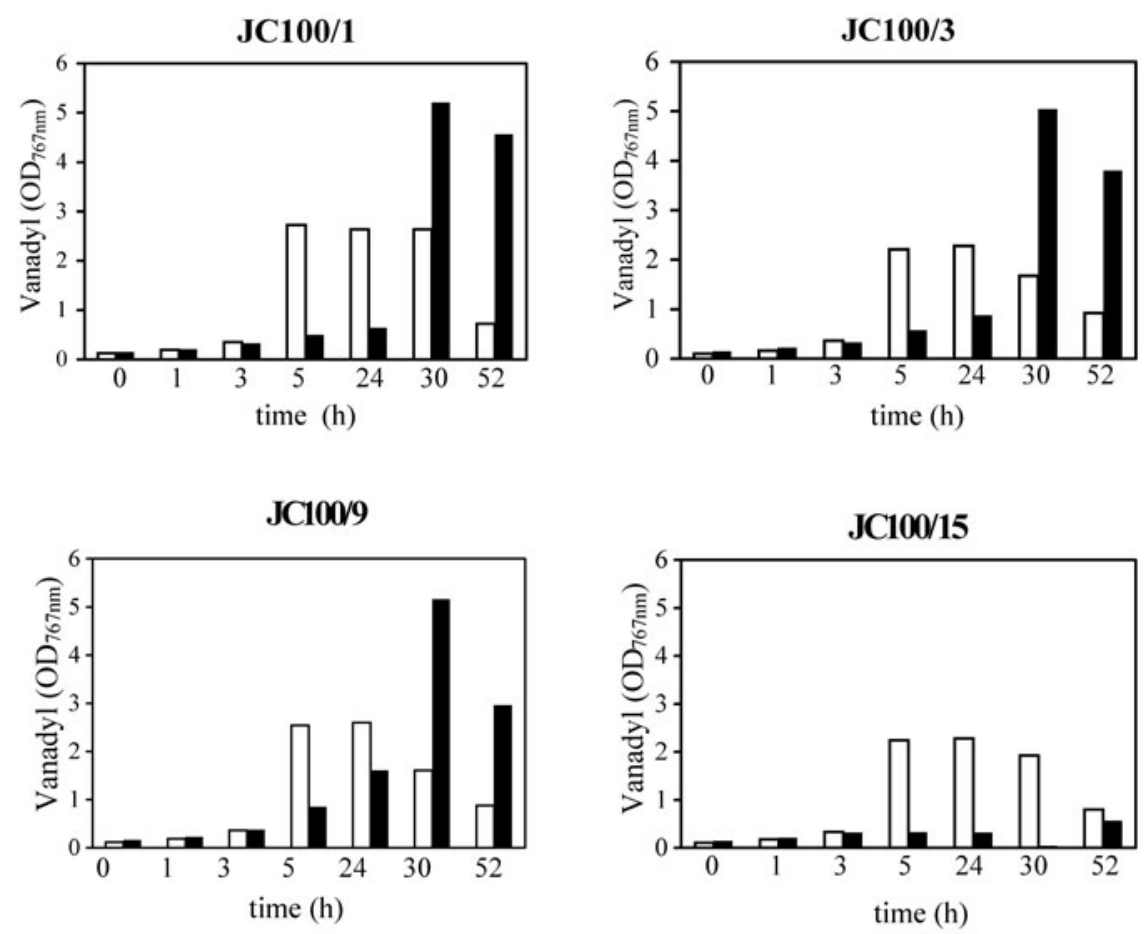

Figure 2. Vanadyl concentration in cell-free medium from cultures of vanadate-resistant $P$. pastoris strains - kinetic studies.

( $\square$ ) Absorbance at $767 \mathrm{~nm}$ in YPD medium in the presence of $25 \mathrm{mM}$ sodium orthovanadate; ( $\square$ ) absorbance at 767 $\mathrm{nm}$ in YPD medium in the presence of $50 \mathrm{mM}$ sodium orthovanadate. The presented results are representative for three independent experiments.

a correlation in the vanadate to vanadyl reduction with yeast growth kinetics. However, identification of the vanadium species present in the growth medium as well as inside $P$. pastoris cells require more thorough quantitative and qualitative analysis by using EPR and NMR spectroscopy. vanadate-resistant strains of $P$. pastoris. For this purpose, yeast cells cultivated to the logarithmic growth phase in the absence and in the presence of $25 \mathrm{mM}$ and $50 \mathrm{mM}$ sodium orthovanadate were collected. Crude PKA fractions, obtained as described in the Materials and methods section, were tested for 
A

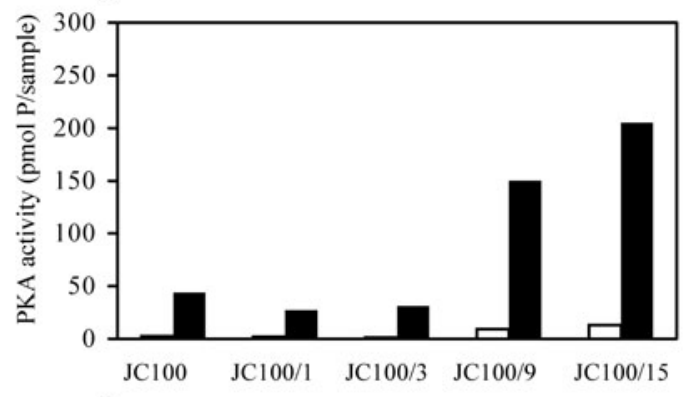

B
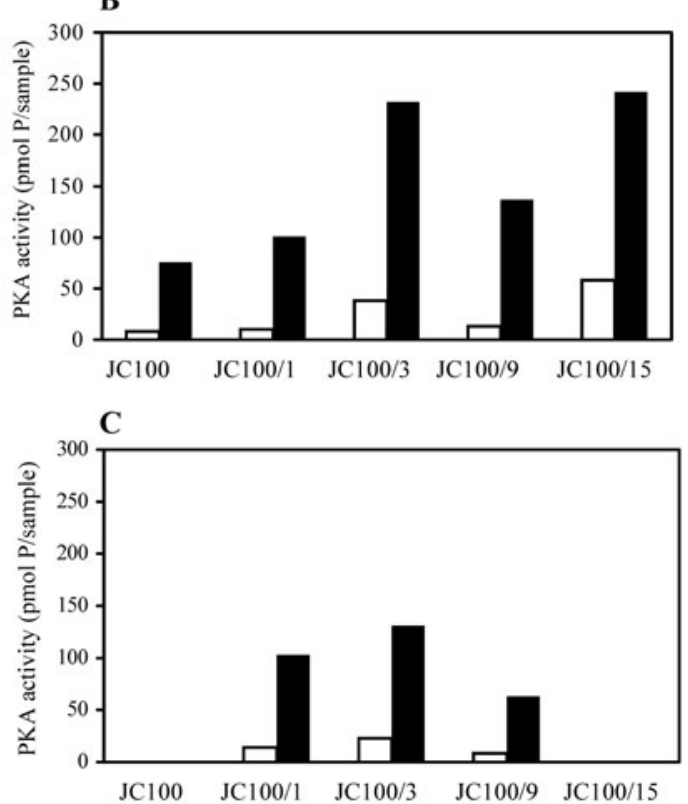

Figure 3. PKA activity in cell-free extracts of wild type and vanadate-resistant $P$. pastoris strains.

Protamine sulfate was used as a phosphorylation substrate in the absence ( $\square$ ) or in the presence of cAMP (ם). The studied strains were grown to the logarithmic phase in liquid YPD medium without vanadate (A), in the presence of $25 \mathrm{mM}$ (B) or $50 \mathrm{mM}$ sodium orthovanadate (C). PKA activity was estimated according to the Materials and Methods section. The presented results are representative for three experiments.

their phosphotransferase activity in the presence of cAMP using protamine sulfate as a substrate. As can be seen in Fig. 3, in the case of cells grown in the medium without vanadate, $\mathrm{PKA}$ activity was detected in all the $P$. pastoris strains studied. In the vanadate-resistant strains JC100/9 and JC100/15, the PKA activity was at least 5 times higher in comparison to the wild type JC100 strain. Furthermore, in cells from cultures contain-
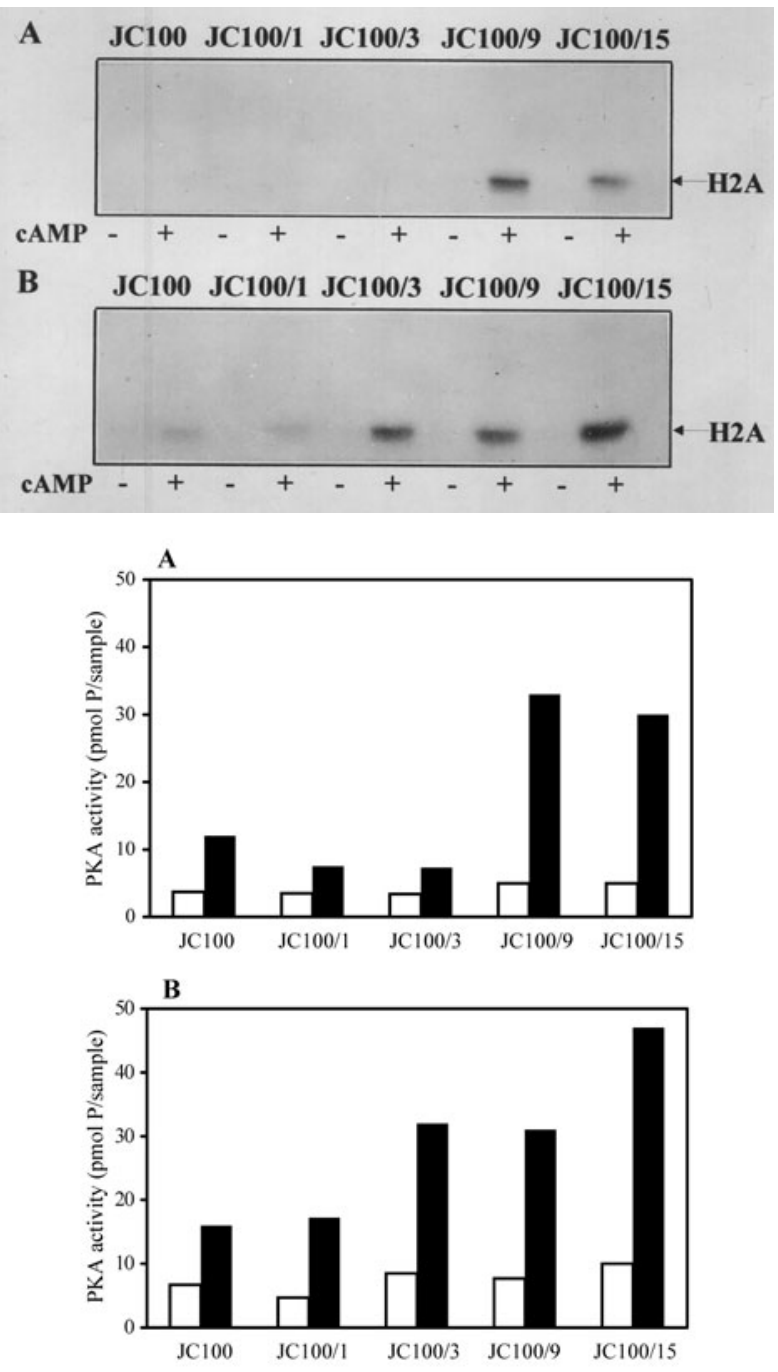

Figure 4. Phosphorylation of histone H2A by PKA from wild type and vanadate-resistant strains of $P$. pastoris.

The studied strains were grown in YPD medium without (A) and in the presence of $25 \mathrm{mM}$ sodium orthovanadate (B). PKA activity was estimated as described in the Materials and Methods section, in the absence $(\square)$ and in the presence of cAMP ( $\square$ ) using histone $\mathrm{H} 2 \mathrm{~A}$ as a substrate. Phosphorylation level of H2A was measured in a scintillation counter (diagram) or estimated by SDS/PAGE electrophoresis and subsequent autoradiography (photograph). The presented results are representative for three experiments.

ing $25 \mathrm{mM}$ sodium orthovanadate the PKA activity increased significantly in $\mathrm{JC} 100 / 1$ and $\mathrm{JC} 100 / 3$ while in the case of JC100/9 and $\mathrm{JC} 100 / 15$ it remained on an almost unchanged level in comparison to the results obtained for the control medium. As for cells 


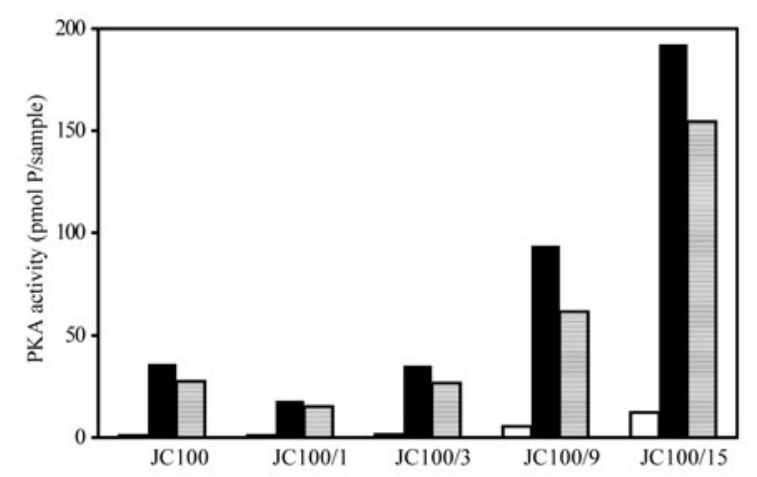

Figure 5. Comparison of PKA activity in the presence of cAMP and cGMP.

PKA activity was measured without $(\square)$, in the presence of cAMP $(\square)$ or cGMP (目) in cell-free extracts of the wild type and vanadate-resistant $P$. pastoris strains. Protamine sulfate was used as a phosphorylation substrate. The studied strains were grown to the logarithmic phase in liquid YPD medium without vanadate. The presented results are representative for three experiments.

which were grown on $50 \mathrm{mM}$ sodium orthovanadate, in strains $\mathrm{JC} 100 / 1, \mathrm{JC} 100 / 3$ and JC100/9 a relatively high PKA activity was observed. Similar results were obtained using histone $\mathrm{H} 2 \mathrm{~A}$ as a phosphorylation substrate (Fig. 4). It is worth mentioning here that all the isolated fractions were stimulated by cAMP and almost to the same level by cGMP (Fig. 5). These results confirm our earlier observations obtained on $S$. cerevisiae indicating that yeast PKA can be activated by both cyclic nucleotides (Cytryńska et al., 1999).

\section{Ribosomal protein phosphorylation in $\boldsymbol{P}$. pastoris vanadate-resistant strains}

In parallel to the studies on PKA activity, we performed a comparative analysis of the proteins modified by kinases associated with ribosomes. For this purpose, membrane-free $80 \mathrm{~S} P$. pastoris ribosomes were incubated with $\left[\gamma_{-}{ }^{32} \mathrm{P}\right] \mathrm{ATP}$ in the absence of exogenous protein kinases. SDS/PAGE and autoradiography analysis of phosphorylated proteins revealed two major radioactive bands of 13 $\mathrm{kDa}$ and $38 \mathrm{kDa}$ in all the strains (Fig. 6).
From earlier studies performed in our laboratory (not shown) we know that they correspond to ribosomal proteins $\mathrm{P} 1 / \mathrm{P} 2$ and $\mathrm{P} 0$, respectively. Isoelectrofocusing analysis of the $\mathrm{P} 1 / \mathrm{P} 2$ proteins extracted from ribosomes re-

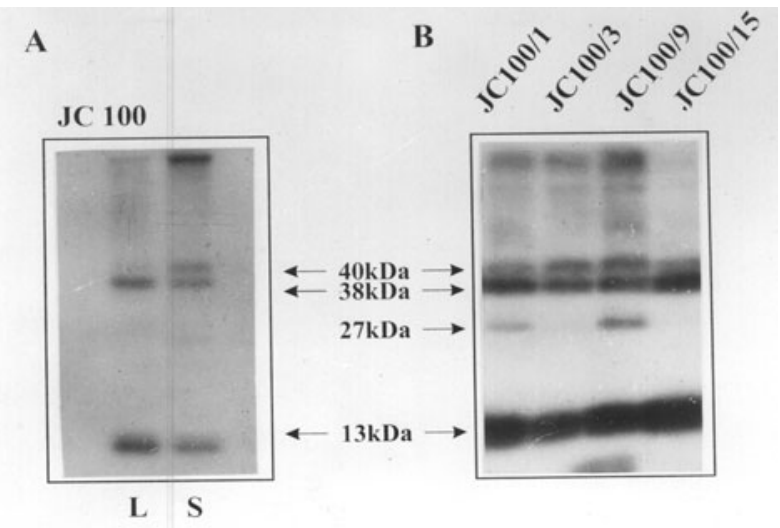

Figure 6. Endogenous protein phosphorylation in membrane-free ribosomes from wild type (A) and vanadate-resistant $P$. pastoris strains (B).

Membrane-free wild type strain ribosomes were isolated from logarithmic (L) or stationary (S) growth phase while ribosomes from the vanadate-resistant strains from logarithmic growth phase only. Yeast cells were grown in liquid YPD medium without vanadate. Ribosomal protein phosphorylation was estimated as described in the Materials and Methods section. The presented autoradiograms are representative for three experiments.

vealed eight forms differing in charge over the acidic $\mathrm{pH}$ range. Four of them were phosphorylated. However, no significant differences in the phosphorylation level between these forms in the yeast strains studied were observed (Fig. 7). In all the vanadate-resistant strains from the logarithmic growth phase an additional phosphoprotein of $40 \mathrm{kDa}$ was detected. In the case of the JC100/1 and $\mathrm{JC} 100 / 9$ strains, a protein of $27 \mathrm{kDa}$ was also phosphorylated (Fig. 6). The protein of $40 \mathrm{kDa}$ was phosphorylated in the wild type strain from the stationary, but not logarithmic, growth phase. This protein could be washed out from ribosomes with a buffer containing $0.5 \mathrm{M} \mathrm{KCl}$ (not shown), which indicated that it is not a structural ribosomal protein but a ribosome-associated one. 


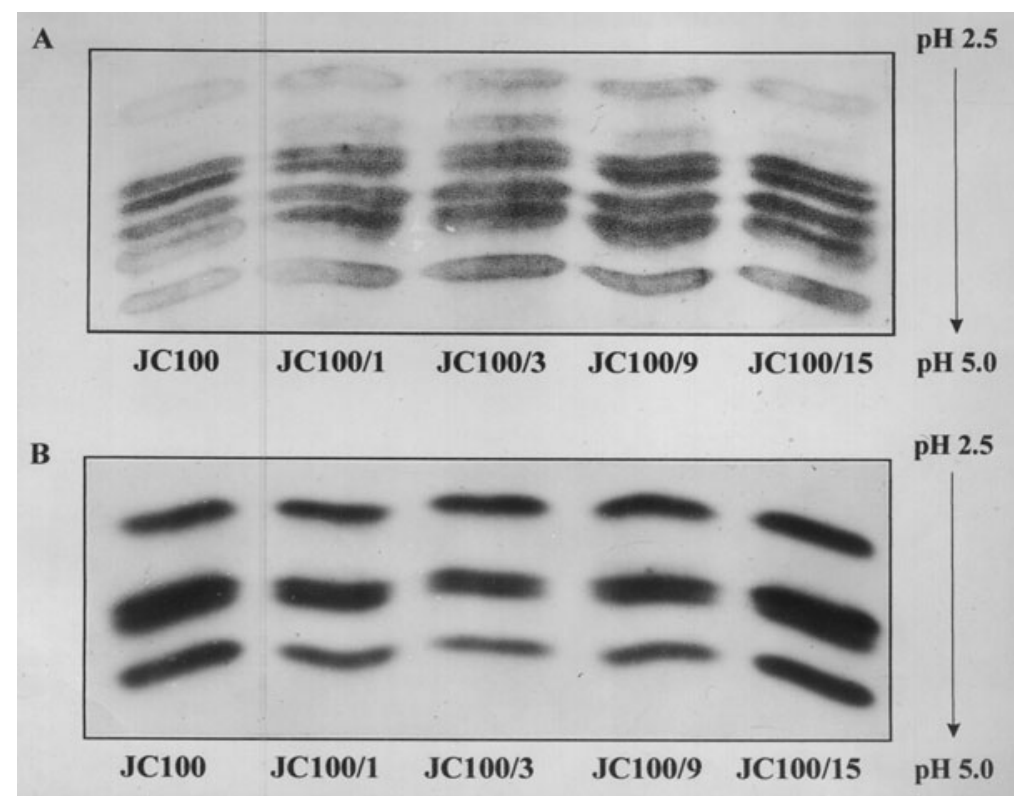

Figure 7. Isoelectrofocusing of acidic ribosomal proteins ${ }^{32}$ P-labelled by ribosome-bound protein kinases.

Acidic proteins were extracted with 0.25 $\mathrm{M} \mathrm{NH}_{4} \mathrm{Cl} / 50 \%$ ethanol from $1.5 \mathrm{mg}$ of ${ }^{32} \mathrm{P}$-labelled ribosomes. IEF was performed as described in the Materials and Methods section. Proteins were detected by silver staining (A) and subsequent autoradiography (B). Yeast cells were grown in liquid YPD medium without vanadate. The presented results are representative for three experiments.

\section{DISCUSSION}

We have shown that the methylotrophic yeast Pichia pastoris is able to grow in the presence of high, up to $25 \mathrm{mM}$, orthovanadate concentrations which are toxic to many other organisms. Furthermore, we selected four $P$. pastoris strains which can tolerate vanadate concentration as high as $150 \mathrm{mM}$. Resistance to such extremely high vanadium salt concentrations (> $96 \mathrm{mM}$ ) was shown for another methylotrophic, thermotolerant yeast species Hansenula polymorpha (Mannazzu et al., 1997). Our results clearly indicate that growth of $P$. pastoris in the presence of vanadate is correlated with reduction of vanadate to vanadyl. However, it is not known if vanadate reduction occurs inside the cell or at the level of the cell envelope as it has been suggested for certain $S$. cerevisiae strains (Bisconti et al., 1997).

It is known from many studies that vanadate acts as a competitor of phosphate molecules and interferes with protein phosphorylation. Moreover, according to Morinville et al. (1998) and Pandey et al. (1995), vanadate, acting as an insulin-mimetic compound, induces activation of MAP kinases and ribosomal protein S6 kinases. Our results demonstrate that in the presence of vanadate in $P$. pastoris wild type strain and two of the selected vanadate- resistant strains, JC100/1 and $\mathrm{JC} 100 / 3$, the level of protein kinase A activity was higher in comparison to the yeast growing without vanadate. It was also found that in two other selected vanadate-resistant strains, JC100/9 and JC100/15, PKA activity was much higher in comparison to the wild type strain even in the absence of vanadate. The constitutively enhanced PKA activity in the $\mathrm{JC} 100 / 9$ and JC100/15 strains can be a result of spontaneous mutation(s) which occured during strain selection in the presence of high vanadate concentration. This, however, requires further studies at the molecular level. Our data also indicate that PKA might be involved in a signalling mechanism induced by vanadate in $P$. pastoris. In addition we have found that in all four vanadate-resistant strains endogenous phosphorylation of a $40 \mathrm{kDa}$ protein associated with ribosomes also occured. This protein was phosphorylated in membrane-free ribosomes from the stationary but not logarithmic growth phase of the wild type $P$. pastoris strain. The role of the $40 \mathrm{kDa}$ protein is not known at present. We cannot exclude the possibility that the $40 \mathrm{kDa}$ protein represents one of the molecules which participate in protecting the cells against stress conditions. This, however, needs further genetic and biochemical studies. 
We would like to thank Monika Koziej for assistance in the manuscript preparation.

\section{R E F E R E N C E S}

Bisconti L, Pepi M, Mangani S, Baldi F. (1997) Reduction of vanadate to vanadyl by a strain of Saccharomyces cerevisiae. BioMetals.; 10: 239-46.

Bowman BJ, Allen KE, Slayman CW. (1983) Vanadate-resistant mutants of Neurospora crassa are deficient in a high-affinity phosphate transport system. J Bacteriol.; 153: 292-6.

Bradford MM. (1976) A rapid and sensitive method for the quantitation of microgram quantities of protein utilizing the principle of protein - dye binding. Anal Biochem.; 72: $248-54$.

Carlson RMK. (1975) Nuclear magnetic resonance spectrum of living tunicate blood cells and the structure of the native vanadium chromogen. Proc Natl Acad Sci U S A.; 72: 2217-21.

Catalan RE, Martinez AM, Aragones MD. (1980) Effects of vanadate on the cyclic AMP-protein kinase system in rat liver. Biochem Biophys Res Commun.; 96: 672-7.

Chasteen ND. (1984) The biochemistry of vanadium. Struct Bonding.; 53: 104-38.

Cytryńska M, Frajnt M, Jakubowicz T. (2001) Saccharomyces cerevisiae pyruvate kinase Pyk1 is PKA phosphorylation substrate in vitro. FEMS Microbiol Lett.; 203: 223-7.

Cytryńska M, Wojda I, Frajnt M, Jakubowicz T. (1999) PKA from Saccharomyces cerevisiae can be activated by cyclic AMP and cyclic GMP. Can J Microbiol.; 45: 31-7.

Goodno CC. (1979) Inhibition of myosin ATPase by vanadate ion. Proc Natl Acad Sci U S A.; 76: $2620-4$.

Gordon JA. (1991) Use of vanadate as proteinphosphotyrosine phosphatase inhibitor. Methods Enzymol.; 201: 477-82.
Hackbarth I, Schmitz W, Scholz H, Wetzel E, Erdmann E, Krawietz W, Philipp G. (1980) Stimulatory effect of vanadate on cyclic AMP levels in cat papillary muscle. Biochem Pharmacol.; 29: 1439-42.

Juan-Vidales F, Saenz-Roblez MT, Ballesta JPG. (1984) Acidic proteins of the large ribosomal subunit in Saccharomyces cerevisiae. Effect of phosphorylation. Biochemistry.; 23: 390-6.

Kanik-Ennulat C, Montalvo E, Neff N. (1995) Sodium orthovanadate-resistant mutants of Saccharomyces cerevisiae show defects in Golgi mediated protein glycosylation, sporulation and detergent resistance. Genetics.; 140: 933-43.

Karlish SJD, Beaugé LA, Glynn IM. (1979) Vanadate inhibits $\left(\mathrm{Na}^{+}+\mathrm{K}^{+}\right)$ATPase by blocking a conformational change of the unphosphorylated form. Nature.; 282: 333-5.

Laemmli UK. (1970) Cleavage of structural proteins during the assembly of the head of bacteriophage T4. Nature.; 227: 680-5.

Lew DJ, Sanford MS. (1991) Characterization of constitutive exocytosis in the yeast Saccharomyces cerevisiae. J Membr Biol.; 123: 261-8.

Lindquist RN, Lynn JL, Lienhard GE. (1973) Possible transition-state analogs for ribonuclease. The complexes of uridine with oxovanadium (IV) ion and vanadium (V) ion. J Am Chem Soc.; 95: 8762-8.

Mahanty SK, Khaware R, Ansari S, Gupta P, Prasad R. (1991) Vanadate-resistant mutants of Candida albicans show alterations in phosphate uptake. FEMS Microbiol Lett.; 68: $163-6$.

Mannazzu I, Guerra E, Strabbioli R, Masia A, Maestrale GB, Zoroddu MA, Fatichenti F. (1997) Vanadium affects vacuolation and phosphate metabolism in Hansenula polymorpha. FEMS Microbiol Lett.; 147: 23-8.

Morinville A, Maysinger D, Shaver A. (1998) From Vanadis to Atropos: vanadium compounds as pharmacological tools in cell death signalling. Trends Pharmacol Sci.; 19: 452-60. 
Pandey SK, Chiasson JL, Srivastava AK. (1995) Vanadium salts stimulate mitogen-activated protein (MAP) kinases and ribosomal S6 kinases. Mol Cell Biochem.; 153: 69-78.

Rehder D. (1992) Structure and function of vanadium compounds in living organisms. BioMetals.; 5: 3-12.

Van der Zeijst BAM, Kool AJ, Bloemers HPJ. (1972) Isolation of active ribosomal subunits from yeast. Eur J Biochem.; 30: 15-25.

Wach A, Graber P. (1991) The plasma membrane $\mathrm{H}^{+}$-ATPase from yeast. Effects of $\mathrm{pH}$, vanadate and erythrosine B on ATP hydrolysis and ATP binding. Eur J Biochem.; 201: 91-7.
Willsky GR, White DA, McCabe BC. (1984) Metabolism of added orthovanadate to vanadyl and high-molecular weight vanadates by Saccharomyces cerevisiae. J Biol Chem.; 259: 13273-81.

Wojda I, Cytryńska M, Frajnt M, Jakubowicz T. (1999) Phosphorylation of yeast ribosomal proteins by CKI and CKII in the presence of heparin. Acta Biochim Polon.; 46: 211-5.

Zoroddu MA, Fruianu M, Dallocchio R, Masia A. (1996) Electron paramagnetic resonance studies and effects of vanadium in Saccharomyces cerevisiae. BioMetals.; 9: 91-7. 